\title{
Rancang Bangun Aplikasi Sistem Pendukung Keputusan Penerima Beasiswa dengan Metode SAW
}

\author{
Wiwit Supriyanti \\ Teknik Informatika Universitas Muhammadiyah Surakarta \\ E-mail: rhianty.alfa@gmail.com
}

\begin{abstract}
Abstrak
Dalam setiap lembaga khususnya universitas, ada banyak beasiswa yang ditawarkan kepada mahasiswa. Ada beasiswa yang bersumber dari pemerintah serta dari pihak swasta. Beasiswa ini dapat diperoleh apabila calon penerima dinilai memenuhi syarat yang telah ditentukan, sebagai contoh: IPK, pendapatan orang tua, jumlah saudara dan jumlah tanggungan orang tua, keaktifan mengikuti organisasi mahasiswa, prestasi dan lain-lain. Saat ini diperlukan aplikasi untuk mengembangkan suatu sistem pendukung keputusan yang dapat memberikan rekomendasi beasiswa agar tepat sasaran dengan banyak kriteria yang dijadikan pertimbangan. Aplikasi yang dibangun untuk menyeleksi penerima beasiswa ini menggunakan program aplikasi lazarus. Metode yang dipilih untuk menyelesaikan permasalahan dengan banyak kriteria adalah Simple Additive Weighting (SAW), salah satu metode yang dapat digunakan untuk memecahkan masalah Fuzzy MADM. Metode ini dipilih karena dapat menentukan bobot untuk setiap atribut, diikuti peringkat alternatif yang akan memilih penerima beasiswa berdasarkan bobot yang telah dibuat untuk mendapatkan hasil yang lebih akurat yang akan menerima beasiswa.
\end{abstract}

Kata Kunci - Beasiswa, Fuzzy MADM, SAW, Kriteria

\begin{abstract}
In any particular university institutions, there are many scholarships are offered to students. There are scholarships from government sources as well as from the private sector. This scholarship can be obtained if considered eligible recipients who have been determined, for example: GPA, parental income, number of siblings and the number of elderly dependents, active following student organizations, and other accomplishments. Currently the application is necessary to develop a decision support system that can provide recommendations for the right target scholarships to many criteria taken into consideration. Applications built for selecting awardees lazarus application program. The method chosen to solve the problem with a lot of criteria is Simple Additive Weighting (SAW), one of the methods that can be used to solve the problem of fuzzy MADM. This method was chosen because it can determine the weights for each attribute, followed by alternative rankings will select scholarship recipients based on the weight that has been made to obtain more accurate results that will receive the scholarship.
\end{abstract}

Keywords — Scholarship, Fuzzy MADM, SAW, criteria 


\section{PENDAHULUAN}

Pada lembaga pendidikan khususnya universitas banyak sekali beasiswa yang ditawarkan kepada mahasiswa yang berprestasi dan bagi mahasiswa yang kurang mampu. Seperti yang dituangkan dalam Undang-Undang Dasar 1945 pasal 31 (1) bahwa tiap-tiap warga Negara berhak mendapatkan pengajaran. Berdasarkan pasal tersebut, maka pemerintah dan pemerintah daerah wajib memberikan layanan dan kemudahan, serta menjamin terselenggaranya pendidikan yang bermutu bagi setiap warga negara tanpa diskriminasi. Untuk menyelenggarakan pendidikan yang bermutu diperlukan biaya pendidikan yang cukup besar. Oleh karena itu bagi setiap peserta didik pada setiap satuan pendidikan berhak mendapatkan biaya pendidikan bagi mereka yang orang tuanya tidak mampu membiayai pendidikannya, dan berhak mendapatkan beasiswa bagi mereka yang berprestasi.

Pemerintah melalui direktorat Jendral Pendidikan Tinggi Departemen Pendidikan Nasional berupaya mengalokasikan dana untuk memberikan beasiswa kepada mahasiswa yang secara ekonomi tidak mampu untuk membiayai pendidikannya, dan memberikan beasiswa kepada mahasiswa yang mempunyai prestasi. Agar program beasiswa dapat dilaksanakan sesuai dengan prinsip 3T yaitu Tepat sasaran, Tepat jumlah dan Tepat waktu. Pengambilan keputusan yang tepat memungkinkan tujuan pelaksanaan beasiswa dapat tercapai dengan menetapkan prinsip 3T tersebut.

Pemberian bantuan belajar berupa beasiswa juga diberikan kepada mahasiswa di Universitas Muhammadiyah Surakarta. Beasiswa yang diberikan antara lain beasiswa Peningkatan Prestasi Akademik (PPA) yang diberikan kepada mahasiswa berprestasi dan beasiswa Bantuan Belajar Mahasiswa (BBM) yang diberikan kepada mahasiswa yang kurang mampu. Dalam menentukan penerima beasiswa telah menggunakan bantuan komputer, tetapi penggunaanya belum optimal. Hal ini menyebabkan pengelolaan data beasiswa yang tidak efisien terutama dari segi waktu dan banyaknya perulangan proses yang sebenarnya dapat diefisienkan. Pengelolaan data beasiswa yang belum terakumulasi menggunakan database secara optimal juga menyebabkan kesulitan dalam pemrosesan data. Sehingga menyebabkan lamanya proses penentuan penerima beasiswa. Oleh karena itu, perlu adanya suatu sistem yang mendukung proses penentuan penerima beasiswa, sehingga dapat mempersingkat waktu penyeleksian dan dapat meningkatkan kualitas keputusan dalam menentukan penerima beasiswa PPA dan BBM.

Salah satu metode yang dapat digunakan untuk meningkatkan pengambilan keputusan dalam menentukan penerima beasiswa yaitu mengunakan logika fuzzy. Menurut Tetamanzi (Kusumadewi, 2006:1) Fuzzy Multiple Attribute Decision Making (Fuzzy MADM) digunakan untuk melakukan penilaian atau seleksi terhadap beberapa alternatif dalam jumlah terbatas. Secara umum dikatakan menyeleksi alternatif terbaik dari sejumlah alternatif yang ada.

Salah satu metode penyelesaian masalah Fuzzy MADM yaitu Simple Additive Weighting (SAW). Konsep dasar SAW adalah mencari penjumlahan terbobot dari rating kinerja pada setiap alternatif pada semua atribut, dalam hal ini yang berhak menerima beasiswa berdasarkan kriteria penerima beasiswa. Dengan metode ini penilaian akan lebih tepat karena didasarkan pada nilai kriteria dan bobot yang sudah ditentukan sehingga akan mendapatkan hasil yang lebih akurat terhadap siapa yang akan menerima beasiswa tersebut.

\subsection{Sistem Pendukung Keputusan}

Keen dan Scoot Morton (Turban, 2005:137) mengatakan sistem pendukung keputusan merupakan penggabungan sumber - sumber kecerdasan individu dengan kemampuan komponen untuk memperbaiki kualitas keputusan. Sistem pendukung keputusan juga merupakan sistem informasi berbasis komputer untuk manajemen pengambilan keputusan yang menangani masalah-masalah semi terstruktur.

Pengambilan keputusan meliputi beberapa tahap dan melalui beberapa proses (Lucas, 1992). Menurut Simon (1960), pengambilan keputusan meliputi empat tahap yang saling berhubungan dan berurutan. Empat proses tersebut adalah: 
1. Intelligence

Tahap ini merupakan proses penelusuran dan pendeteksian dari lingkup problematika serta proses pengenalan masalah. Data masukan diperoleh, diproses, dan diuji dalam rangka mengidentifikasikan masalah.

2. Design

Tahap ini merupakan proses menemukan dan mengembangkan alternatif. Tahap ini meliputi proses untuk mengerti masalah, menurunkan solusi dan menguji kelayakan solusi.

3. Choice

Pada tahap ini dilakukan poses pemilihan di antara berbagai alternatif tindakan yang mungkin dijalankan. Tahap ini meliputi pencarian, evaluasi, dan rekomendasi solusi yang sesuai untuk model yang telah dibuat. Solusi dari model merupakan nilai spesifik untuk variabel hasil pada alternatif yang dipilih.

4. Implementation

Tahap implementasi adalah tahap pelaksanaan dari keputusan yang telah diambil. Pada tahap ini perlu disusun serangkaian tindakan yang terencana, sehingga hasil keputusan dapat dipantau dan disesuaikan apabila diperlukan perbaikan.

\subsection{Fuzzy Logic}

Fuzzy diperkenalkan dalam paper yang dibuat oleh Lofti A Zadeh, dimana Zadeh memperkenalkan teori yang memiliki obyek-obyek dari himpunan fuzzy yang memiliki batasan yang tidak pretisi dan keanggotaan dalam himpunan fuzzy, bukan dalam bentuk logika benar (true) atau salah (false), tetapi dinyatakan dalam bentuk derajat (degree). Konsep ini disebut Fuzziness dan teorinya dinamakan Fuzzy Set Theory. Fuzzy logic merupakan studi tentang metode dan prinsip-prinsip pemikiran dimana pemikiran tersebut menghasilkan preposisi yang baru dari preposisi yang lama. Pada logika lama, preposisi diperlukan diantara true dan false, nilai kebenaran dari preposisi tersebut antara 1 atau 0. Fuzzy logic membuat pernyataan umum dari dua nilai logika lama dengan cara menyertakan nilai kebenaran dari sebuah preposisi untuk dijadikan sembarang angka diantara interval $(1,0)$.

\subsection{Fuzzy Multiple Attribute Decision Making (FMADM)}

Fuzzy Multiple Attribute Decision Making (FMADM) adalah suatu metode yang digunakan untuk mencari alternatif optimal dari sejumlah alternatif dengan kriteria tertentu. Inti dari Fuzzy MADM adalah menentukan nilai bobot untuk setiap atribut, kemudian dilanjutkan dengan proses perankingan yang akan menyeleksi alternatif yang sudah diberikan. Pada dasarnya, ada 3 pendekatan untuk mencari nilai bobot atribut, yaitu pendekatan subyektif, pendekatan obyektif dan pendekatan integrasi antara subyektif dan obyektif. Masing-masing pendekatan memiliki kelebihan dan kelemahan. Pada pendekatan subyektif, nilai bobot ditentukan berdasarkan subyektifitas dari para pengambil keputusan, sehingga beberapa faktor dalam proses perankingan alternatif bisa ditentukan secara bebas. Sedangkan pada pendekatan obyektif, nilai bobot dihitung secara matematis sehingga mengabaikan subyektifitas dari pengambil keputusan.

Ada beberapa metode yang dapat digunakan untuk menyelesaikan masalah FMADM antara lain:

1. Simple Additive Weighting (SAW)

2. Weighted Product (WP)

3. Elimination Et Choix Traduisant la Realite (ELECTRE)

4. Technique for Order Preference by Similarity to Ideal Solution (TOPSIS)

5. Analytical Hierarchy Process (AHP) 


\subsection{Simple Additive Weighting (SAW)}

Metode Simple Additive Weighting (SAW) sering juga dikenal istilah metode penjumlahan terbobot. Konsep dasar metode SAW adalah mencari penjumlahan terbobot dari rating kinerja pada setiap alternatif pada semua atribut (Fishburn, 1967) (MacCrimmon, 1968). Metode SAW membutuhkan proses normalisasi matriks keputusan (X) ke suatu skala yang dapat diperbandingkan dengan semua rating alternatif yang ada.

Formula untuk melakukan normalisasi tersebut adalah sebagai berikut:

$$
r_{i j}= \begin{cases}\frac{x_{i j}}{\operatorname{Max}_{i}} & j i k a \text { j adalah atribut keuntungan (benefit) } \\ \frac{\operatorname{Min}_{i} x_{i j}}{x_{i j}} & \text { jika jadalah atribut biaya (cost) }\end{cases}
$$

dengan $r_{i j}$ adalah rating kinerja ternormalisasi dari alternatif $A_{i}$ pada atribut $C_{j} ; i=1,2, \ldots, m$ dan $\mathrm{j}=1,2, \ldots, \mathrm{n}$.

Nilai preferensi untuk setiap alternatif $\left(\mathrm{V}_{\mathrm{i}}\right)$ diberikan sebagai berikut:

$$
V_{i}=\sum_{j=1}^{n} w_{j} r_{i j}
$$

Nilai $V_{i}$ yang lebih besar mengindikasikan bahwa alternatif $A_{i}$ lebih terpilih.

Langkah penyelesaian Fuzzy MADM menggunakan metode SAW:

1. Menentukan kriteria yang dijadikan acuan pengambilan keputusan.

2. Menentukan rating kecocokan setiap alternatif pada setiap kriteria.

3. Membuat matriks keputusan berdasarkan kriteria, kemudian melakukan normalisasi matriks berdasarkan persamaan yang disesuaikan dengan jenis atribut sehingga diperoleh matriks ternormalisasi R.

4. Hasil akhir diperoleh dari proses perangkingan yaitu penjumlahan dari perkalian matriks ternormalisasi $\mathrm{R}$ dengan vektor bobot sehingga diperoleh nilai terbesar yang dipilih sebagai alternatif terbaik sebagai solusi.

\subsection{Lazarus}

IDE Lazarus muncul dari bahasa pemrograman Pascal. Lazarus adalah bahasa pemrograman yang mempunyai cakupan kemampuan yang luas dan canggih. Lazarus merupakan bahasa pemrograman yang berorientasi pada objek yang maksudnya adalah object, property, dan prosedure dikemas dalam satu kemasan. Secara umum, kemampuanLazarus adalah menyediakan komponen-komponen dan bahasa pemrograman yang handal dan lengkap serta memiliki lingkungan pemrograman Integrated Development Environment (IDE). Dengan IDE semua yang diperlukan dalam pengembangan kondisi normal semua tersedia.

\section{6. $M Y S Q L$}

Menurut Nugroho (2004:29) memberi penjelasanbahwa "Salah satu aplikasi basis data adalah Mysql yang merupakan sebuah program pembuat basis data yang bersifat Open Source, artinya siapa saja boleh menggunakannya dan tidak dicekal".

Secara umum, kelebihan MySQL adalah tersedianya gratis untuk banyak sistem operasi dan hardware, memiliki kecepatan proses dan kemampuan menangani database dengan sangat baik di tipe hardware dan sistem operasi yang digunakan. 
Selain itu MySQL juga mudah digunakan karena bahasa yang digunakannya termasuk simple, mendukung. SQL (Structure Query Language), sebuah bahasa untuk semua database sistem yang modern, mampu bekerja dengan beban berat dengan banyak client yang terhubung dalam satu waktu secara bersamaan, dapat diakses dari mana saja dari internet, mudah diperoleh dan terakhir faktor keamanan yang terjamin. Mampu menangani jutaan user dalam waktu bersamaan.

Kekurangan dari MySQL hanya pada tidak adanya fasilitas transaction processing.

\section{METODE PENELITIAN}

\subsection{Metodologi Penelitian}

Metodologi penelitian yang digunakan dalam sistem pendukung keputusan untuk penerima beasiswa ini adalah SDLC (Systems Development Life Cycle).

Tahapan-tahapan SDLC antara lain:

a. Studi kelayakan

Studi kelayakan bertujuan untuk mengetahui apakah sistem baru tersebut realistis dalam masalah pembiayaan, waktu, serta perbedaan dengan sistem yang ada sekarang. Biasanya dalam tahap studi kelayakan ini diputuskan untuk meng-update sistem yang ada atau menggantinya dengan sistem yang baru.

b. Analisis

Pengguna dan software developer bekerjasama mengumpulkan, mempelajari, dan merumuskan kebutuhan-kebutuhan bisnis.

c. Desain

Pembuatan blueprint sistem dan penyesuaian dengan arsitektur telekomunikasi, hardware, dan software untuk pengembangan lebih lanjut, serta membuat model sistem menciptakan model graphical user interface, database, dan lain-lain.

d. Pengembangan

Pada tahapan ini, barulah para programmer melakukan coding untuk menerapkan desain ke dalam sistem yang sesungguhnya, membuat program, dan menyiapkan database.

e. Pengujian

Setelah sistem berhasil dikembangkan, langkah selanjutnya adalah pengujian untuk melihat apakah sistem telah sesuai dengan harapan dan kebutuhan pengguna.

f. Implementasi

Tahap ini, software yang telah diuji siap diimplementasikan ke dalam sistem pengguna. Pembuatan user guide dan pelatihan juga dilakukan.

\subsection{Tipe Penelitian}

Jenis penelitian yang digunakan dalam pembuatan aplikasi sistem pendukung keputusan ini adalah deskriptif dan empiris. Penelitian deskriptif adalah proses pemecahan masalah dengan mencari subjek dan objek pada administrasi beasiswa pada umumnya, sedangkan empiris artinya meneliti langsung peristiwa-peristiwa yang ada di lapangan.

\subsection{Metode Pengumpulan Data}

Dalam melakukan penelitian untuk mendapatkan data dan informasi, maka metode yang digunakan dalam proses pengumpulan data dilakukan sebagai berikut :

1. Metode Observasi

Dalam hal ini yang akan dilakukan adalah melihat serta mempelajari permasalahan yang ada dilapangan yang erat kaitannya dengan objek yang diteliti yaitu informasi mengenai sistem penentuan beasiswa. 
2. Metode Studi Pustaka

Metode yang dilakukan adalah dengan cara mencari bahan yang mendukung dalam pendefinisian masalah melalui buku-buku, internet, yang erat kaitannya dengan objek permasalahan.

3. Metode Analisa Data

Sistem pendukung keputusan yang akan dibuat menggunakan Fuzzy MADM (Multiple Attribute Decision Making) dengan metode Simple Additive Weighting (SAW) untuk menentukan siapa yang akan menerima beasiswa berdasarkan bobot penilaian dan kriteria yang sudah ditentukan.

\section{HASIL DAN PEMBAHASAN}

\subsection{Kriteria - Kriteria Yang Digunakan}

Kriteria-kriteria yang digunakan adalah sebagai berikut:

1. $\mathrm{C} 1=$ Nilai indeks prestasi akademik (IPK)

2. $\mathrm{C} 2=$ Penghasilan orang tua

3. $\mathrm{C} 3=$ Prestasi yang pernah diraih

4. $\mathrm{C} 4=$ Organisasi mahasiswa yang diikuti

5. $\mathrm{C} 5=$ Jumlah tanggungan orang tua

\subsection{Bobot Kriteria} berikut:

Dari kelima kriteria yang telah dibuat, masing-masing kriteria diberi bobot sebagai

1. $\mathrm{C} 1=0,26$

2. $\mathrm{C} 2=0,23$

3. $\mathrm{C} 3=0,15$

4. $\mathrm{C} 4=0,14$

5. $\mathrm{C} 5=0,22$

Tabel 1. Bobot Kriteria IPK

\begin{tabular}{|l|l|}
\hline Nilai IPK & Bobot \\
\hline IPK $<=2,75$ & 0 \\
\hline $2,75<$ IPK $<=3,00$ & 0,25 \\
\hline $3,00<$ IPK <= 3,25 & 0,5 \\
\hline $3,25<$ IPK <=3,50 & 0,75 \\
\hline IPK $>3,50$ & 1 \\
\hline
\end{tabular}

Tabel 2. Bobot Kriteria Penghasilan Orang Tua

\begin{tabular}{|l|l|}
\hline Besar Gaji & Bobot \\
\hline Gaji $<=1.000 .000$ & 1 \\
\hline $1.000 .000<$ Gaji $<=5.000 .000$ & 0,75 \\
\hline $5.000 .000<$ Gaji $<=10.000 .000$ & 0,5 \\
\hline Gaji $>10.000 .000$ & 0,25 \\
\hline
\end{tabular}

Tabel 3. Bobot Kriteria Prestasi

\begin{tabular}{|l|l|}
\hline Prestasi Yang Diraih & Bobot \\
\hline Ada & 1 \\
\hline Tidak Ada & 0,5 \\
\hline
\end{tabular}


Citec Journal, Vol. 1, No. 1, November 2013 - Januari 2014

Tabel 4 Bobot Kriteria Keaktifan Dalam Organisasi

\begin{tabular}{|l|l|}
\hline Partisipasi Dalam Organisasi & Bobot \\
\hline Aktif & 1 \\
\hline Tidak Aktif & 0,5 \\
\hline
\end{tabular}

Tabel 5. Bobot Kriteria Jumlah Tanggungan

\begin{tabular}{|l|l|}
\hline Jumlah Anak & Bobot \\
\hline 1 anak & 0 \\
\hline 2 anak & 0,25 \\
\hline 3 anak & 0,5 \\
\hline 4 anak & 0,75 \\
\hline$>=5$ anak & 1 \\
\hline
\end{tabular}

\subsection{Implementasi Pada Program Aplikasi}

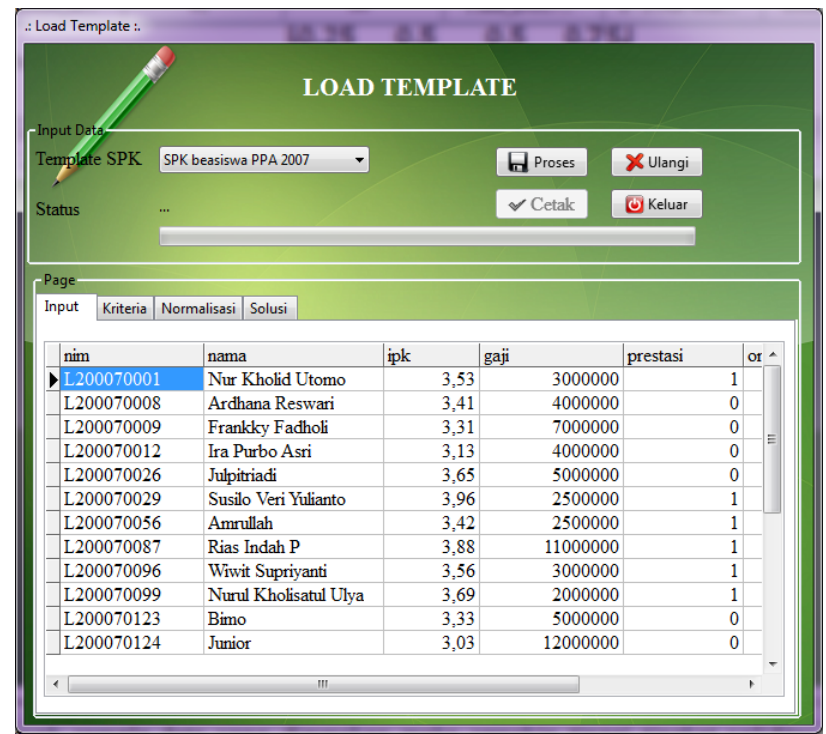

Gambar 1. Tampilan Program Bagian Input Data

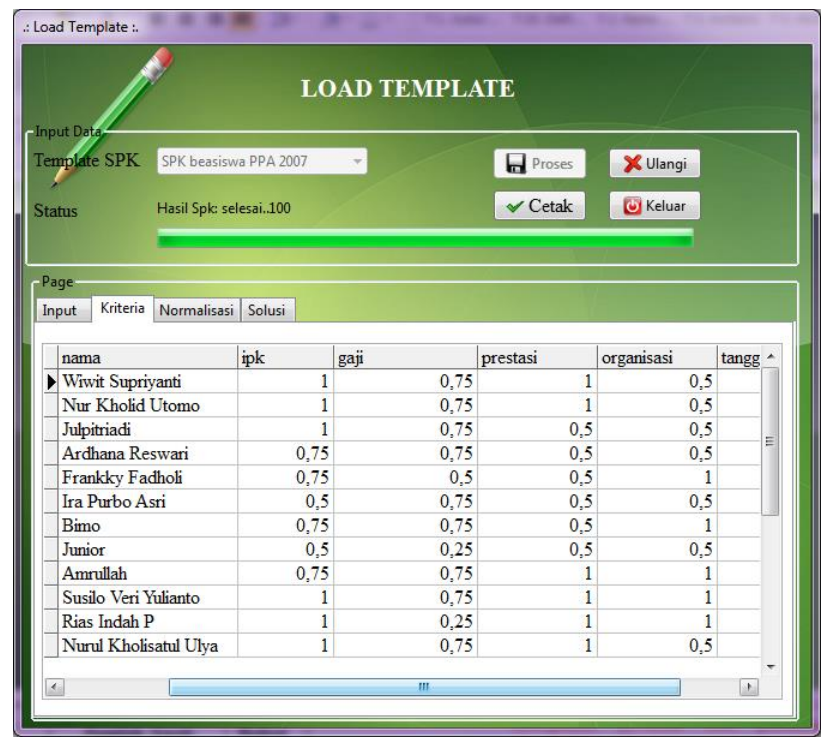

Gambar 2. Tampilan Program Tahap Pembobotan 


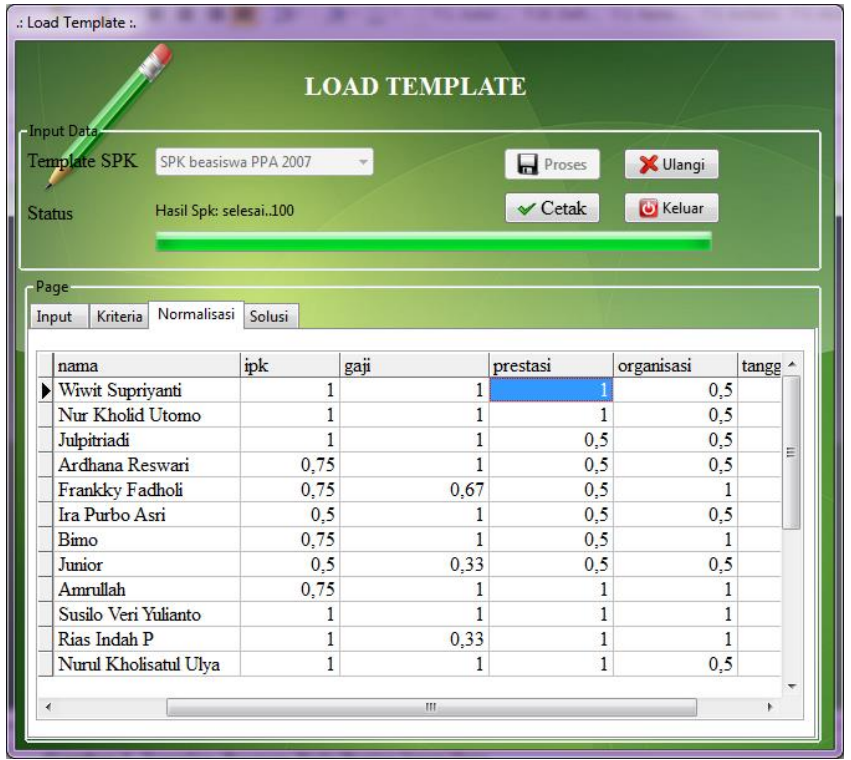

Gambar 3. Tampilan Program Tahap Normalisasi

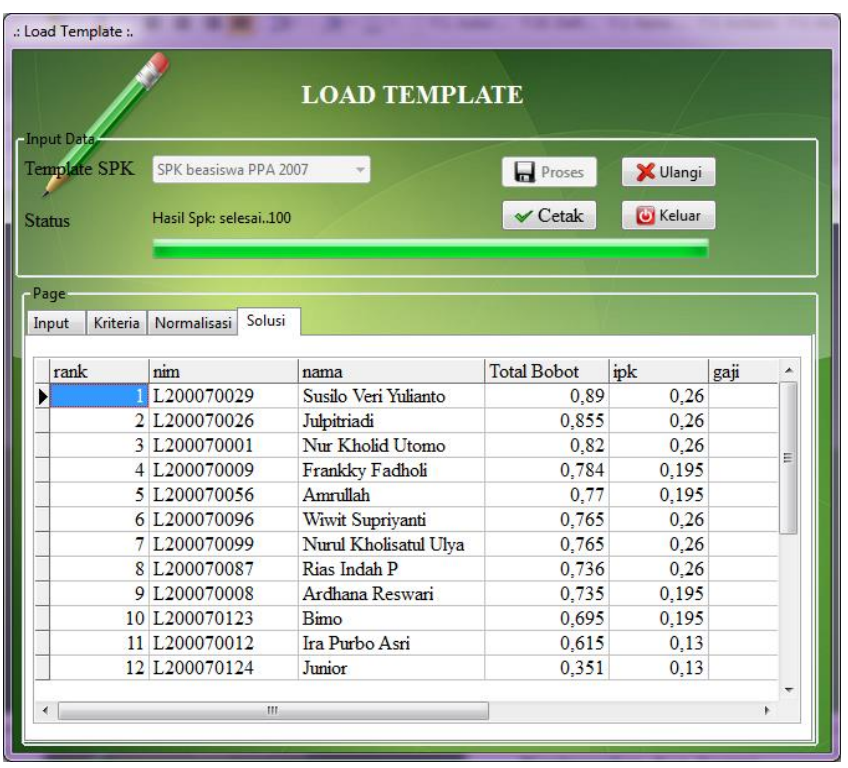

Gambar 4. Tampilan Program Tahap Solusi / Hasil 
Citec Journal, Vol. 1, No. 1, November 2013 - Januari 2014

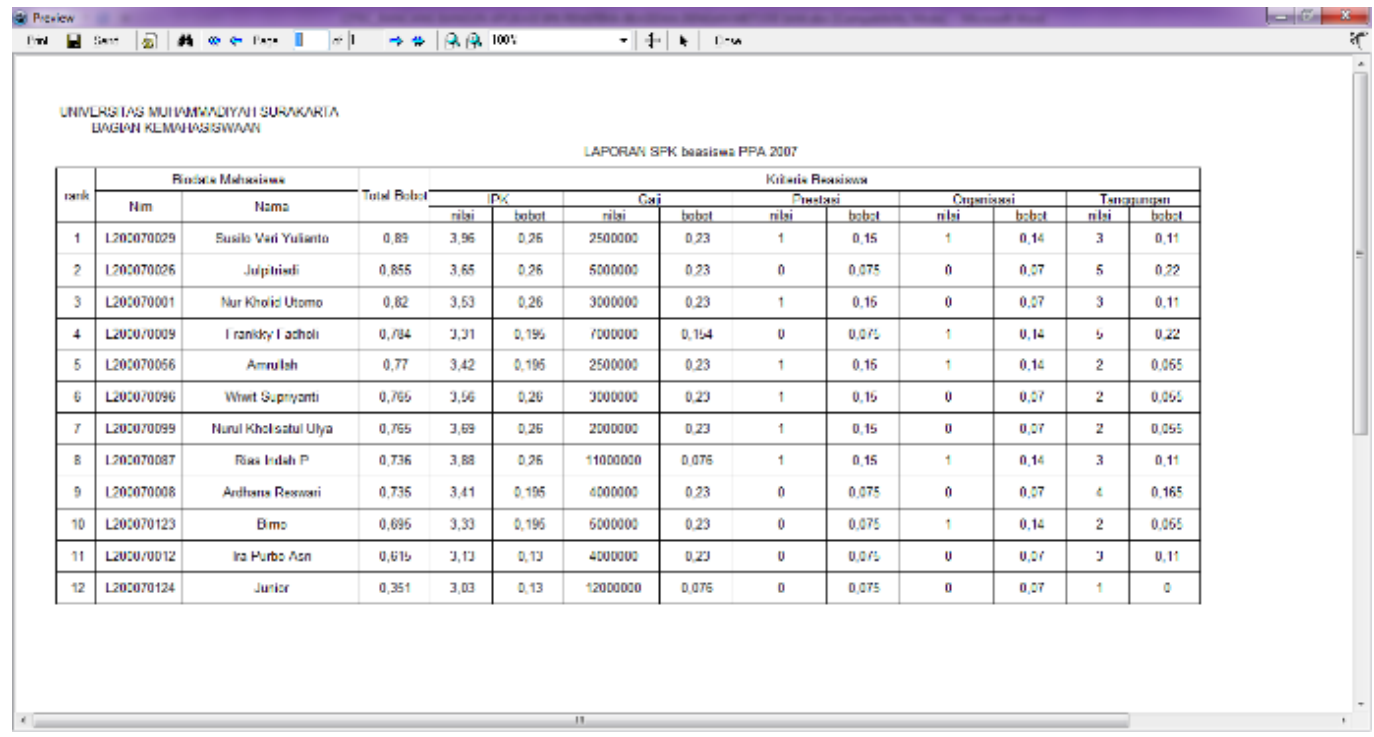

Gambar 5. Laporan Daftar Penerima Beasiswa

\section{KESIMPULAN}

Dibangunnya sistem pendukung keputusan untuk membantu menentukan penerima beasiswa menggunakan metode Simple Additive Weighting (SAW) yang dapat mempercepat proses menentukan penerima beasiswa dengan perhitungan yang akurat dalam memberikan rekomendasi penerima beasiswa.

Semakin banyak sample data yang digunakan maka semakin tinggi pula tingkat validitas perhitungan yang dihasilkan.

Pemberian skala konversi dan bobot preferensi dari setiap bobot kriteria mempengaruhi penilaian dan hasil perhitungan SAW.

\section{SARAN}

Dalam penelitian yang telah dilakukan digunakan lima kriteria, bagi pengembang bisa melakukan modifikasi untuk kriteria serta bobotnya (ditambah ataupun dikurangi) sesuai kebutuhan.

\section{DAFTAR PUSTAKA}

[1] Turban, E., et al., 2005, Decision Support Systems and Intelligent Systems, Andi, Yogyakarta.

[2] McLeod, R. Jr, 1995, Management Information System, 6th Ed, Prentice Hall. Inc, New Jersey.

[3] Kusumadewi, S., dkk, 2006, Fuzzy Multi-Atribute Decision Making (Fuzzy MADM), Graha Ilmu, Yogyakarta.

[4] Nugroho, B., 2004, PHP \& MySQL dengan Editor Dreamweaver MX, Andi, Yogyakarta.

[5] Putra, A., Hardiyanti, D. Y., 2011, Penentuan Penerima Beasiswa dengan Menggunakan Fuzzy MADM, Seminar Nasional Informatika 2011 (semnasIF 2011), Yogyakarta, 2 Juli 2011. 